\title{
The Shariah Compliance Analysis Based On Financial Ratio Aspects (Study Of Companies That Are Always Listed Onthe Indonesian Sharia Stock Index)
}

\author{
Evan Hamzah Muchtar' \\ Department of Sharia Banking STAI Asy-Syukriyyah Tangerang \\ Email: evan.hamzah.m@gmail.com
}

\begin{abstract}
Sharia products in the capital market develop through a variety of sharia investment products that continue to increase in number and are supported by strong regulations, both in terms of the Financial Services Authority (OJK) and the National Sharia Council of the Indonesian Ulema Council (DSN MUI). The screening process for sharia shares includes two aspects that must be fulfilled by issuers in order to enter the sharia stock index, namely the qualitative and quantitative aspects. This paper will discuss problems that arise and raise debates among academics and Islamic practitioners in the screening process for stocks listed on the Islamic stock index and the shariah compliance analysis based on finantial ratio aspects.
\end{abstract}

Keywords: Sharia Compliance, Finantial Ratio Aspects

\begin{abstract}
ABSTRAK
Produk syariah di pasar modal berkembang melalui berbagai produk investasi syariah yang terus meningkat jumlahnya dan didukung oleh regulasi yang kuat, baik dari sisi Otoritas Jasa Keuangan (OJK) maupun Dewan Syariah Nasional Majelis Ulama Indonesia (DSN). MUI). Proses penapisan saham syariah mencakup dua aspek yang harus dipenuhi emiten untuk masuk ke dalam indeks saham syariah, yaitu aspek kualitatif dan kuantitatif. Makalah ini akan membahas permasalahan yang muncul dan menimbulkan perdebatan di kalangan akademisi dan praktisi syariah dalam proses penyaringan saham yang terdaftar di indeks saham syariah dan analisis kepatuhan syariah berdasarkan aspek rasio keuangan.
\end{abstract}

Kata kunci: KepatuhanSyariah, AspekRasioKeuangan

\section{A. INTRODUCTION}

Sharia products are an alternative investment in the Indonesian capital market. Overall, the Indonesian sharia capital market is developed through a product publishing approach that meets shariah criteria, complemented by sharia supervision institutions within the framework and structure of the national capital market that has been based on conventional systems. The process of issuing and

\footnotetext{
${ }^{1}$ Department of Sharia Banking STAI Asy-SyukriyyahTangerang
} 
Evan Hamzah Muchtar :The Shariah Compliance Analysis...

trading capital market products that meet sharia criteria is carried out in parallel with the process of issuing and trading conventional products. ${ }^{2}$

In order to make it easier for sharia capital market players to choose sharia shares, the Financial Services Authority (OJK) issues a List of Sharia Securities (DES) that contains shares that meet the criteria for sharia shares. DES was first issued in 2007 as an implementation of Regulation No. II.K.1 concerning Criteria and Issuance of List of Sharia Securities. Furthermore, DES is updated periodically 2 (two) times a year, namely at the end of May and the end of November. In addition, an incidental DES was issued for the issuer's shares which had been effective for their registration statement and fulfilled the criteria as sharia shares. ${ }^{3}$

Based on the Indonesian Sharia Stock Index (ISSI), which has been issued from 2011 to 2018, the number of sharia shares has increased from year to year as shown in table 1 . The increase in the number of sharia shares is in line with the increase in the number of companies offering public shares and increasing issuers its shares meet the criteria as sharia shares.

Tabel 1

Development of Sharia Shares

\begin{tabular}{|c|c|c|}
\hline \multirow{2}{*}{ Years } & Period & Total Sharia Share \\
\hline \multirow{2}{*}{2011} & I & 212 \\
\cline { 2 - 3 } & II & 235 \\
\hline \multirow{2}{*}{2012} & I & 269 \\
\cline { 2 - 3 } & II & 300 \\
\hline \multirow{2}{*}{2013} & I & 286 \\
\cline { 2 - 3 } & II & 311 \\
\hline \multirow{2}{*}{2014} & I & 305 \\
\cline { 2 - 3 } 2015 & II & 316 \\
\cline { 2 - 3 } & I & 313 \\
\hline \multirow{2}{*}{2016} & II & 315 \\
\cline { 2 - 3 } & I & 306 \\
\hline \multirow{2}{*}{2017} & II & 331 \\
\cline { 2 - 3 } & II & 335 \\
\hline \multirow{2}{*}{2018} & I & 361 \\
\cline { 2 - 3 } & II & 368 \\
\hline
\end{tabular}

${ }^{2}$ AndriSoemitra, MasaDepanPasar Modal Syariah Di Indonesia EdisiRevisi, (Jakarta: Kencana, 2016), p.223

${ }^{3}$ Sharia Capital Market Directorate OJK. Roadmap Pasar Modal Syariah2015-2019. (Jakarta: DirektoratPasar Modal Syariah OJK, 2015) p.30 
Evan Hamzah Muchtar :The Shariah Compliance Analysis...

\section{Source: OtoritasJasaKeuangan ${ }^{4}$}

Sharia products in the capital market develop through a variety of sharia investment products that continue to increase in number and are supported by strong regulations, both in terms of the Financial Services Authority and the National Sharia Council of the Indonesian Ulema Council. This has proven to be able to substantially increase the number of Islamic investors. As of December 2018, the number of Shariah investors was 44,536, investors increased by $92 \%$ when compared to the end of 2017 which was only 23,207. The total number of sharia investors actively conducting transactions also increased to $56 \%$ from the previous year of $35 \% .^{5}$

\section{B. CRITERIA FOR LIST OF SHARIA SECURITIES}

In the context of developing the Islamic Capital Market in order to grow stably and sustainably, it is necessary to develop adequate market infrastructure. One important market infrastructure is the availability of clear, easy-to-understand, and enforceable regulations so that they become market-friendly regulations.

The dynamics of the development of the Islamic Capital Market require the improvement of Rule Number IX.A.13, Attachment of the Decree of the Chairperson of the Capital Market and Financial Institution Supervisory Agency Number: KEP181 / BL / 2009 dated 30 June 2009 concerning Issuance of Sharia Securities, to suit the needs of the Market industry Islamic capital, generally accepted practices, and international standards.

On November 3, 2015 issued the Financial Services Authority Regulation Number 15 / POJK.04 / 2015 concerning the Application of Sharia Principles in the Capital Market to improve Regulation Number IX.A.13, Attachment to the Decision of the Chairperson of the Capital Market and Financial Institution Supervisory Agency Number Kep-181 / BL / 2009 dated 30 June 2009 concerning Issuance of Sharia Securities, which regulates among other things the application of Sharia Principles in the Capital Market in Sharia Activities in the Capital Market and / or activities and types of business, ways of managing the business carried out, and products or

${ }^{4}$ Financial Service Authority, Pengumuman Perubahan Komposisi Saham dalam Perhitungan Indeks Saham Syariah Indonesia (ISSI), 2011-2018

${ }^{5}$ Indonesia Stock Exchange, Annual Report 2018, p.128 
Evan Hamzah Muchtar :The Shariah Compliance Analysis...

services issued based on the principle sharia. Some of the principal improvements in the Financial Services Authority Regulation include the types of business activities that are contrary to the Sharia Principles in the Capital Market, transactions that are contrary to the Sharia Principles in the Capital Market, obligations for Parties conducting Sharia Activities in the Capital Market, and reports on compliance with Sharia Principles in the Capital Market.

Sharia principles in the Capital Market are Islamic legal principles in Sharia Activities in the Capital Market based on the fatwa of the National Sharia Council Indonesian Ulema Council (DSN MUI), as long as the fatwa referred does not conflict with this Financial Services Authority Regulation and / or other Financial Services Authority Regulations based on on the MUI DSN fatwa.

Activities and types of business that are contrary to Sharia Principles in the Capital Market include 6 , among others: (1) Gambling and games that are classified as gambling; (2) Ribawi financial services7; (3) Buying and selling risks that contain elements of uncertainty (gharar) ${ }^{8}$ and / or gambling (maisir) ${ }^{9}$; and (4) produce, distribute, trade and / or provide illicit goods or services ${ }^{10}$.

Transactions that are contrary to Sharia Principles in the Capital Market include11, among others: (1) Trade or transactions with false offers and / or requests $^{12}$; (2) Trade or transactions that are not accompanied by the delivery of

6Financial Services Authority Regulations No.15/POJK.04/2015 Article 2 section (1)

${ }^{7}$ Examples of ribawi financial services include interest-based banks and interest-based finance companies

8 What is meant by gharar is obscurity that causes disputes. Examples of buying and selling risks that contain an element of uncertainty (gharar) include conventional insurance and derivative transactions (forward, futures, swaps) or options that contain speculation

${ }^{9}$ What is meant by means of Maisir is any activity involving gambling where the party that wins gambling will take the bet and the losing party will lose the bet

10 Unlawful goods or services (illicit li-zatihi), illicit goods or services not because of the substances (unlawful li-ghairihi) stipulated by DSN MUI and goods or services that are morally damaging and mudharat. Examples of illicit goods or services (illicit li-dzatihi) include alcoholic beverages, animals that are prohibited from sharia, and their derivative products. Examples of illicit goods or services not because of the substance (haram li-ghairihi) include meat from sharia lawful animals but slaughtered without reading basmalah. Examples of goods or services that are morally damaging and damaging are cigarettes, media and / or service providers that contain pornography and porno-action elements.

${ }^{11}$ Financial Services Authority Regulations No.15/P0JK.04/2015 Article 2 section (2)

${ }^{12}$ Examples of trades with fake offers or requests (najsy) are Securities transactions that are initiated by price movements that tend to rise (uptrend), which are caused by a series of transactions that are deliberately carried out by the buying initiator to form prices up to the highest level they want (pump and dump) and transactions that are accompanied by positive information that is not true, exaggerated, misleading (hype and dump). 
Evan Hamzah Muchtar :The Shariah Compliance Analysis...

goods and / or services; (3) Trading on goods not yet owned ${ }^{13}$; (4) Purchase or sale of Securities using or using inside information from Issuers or Public Companies'4;

(5) Margin transactions on Sharia Securities containing interest (usury) elements;

(6) Trade or transactions for the purpose of hoarding (ihtikar) ${ }^{15}$; (7) Conducting trade or transactions containing elements of bribery (risywah) ${ }^{16}$; and (8) Other transactions that contain elements of speculation (gharar), fraud (tadlis) ${ }^{17}$ including hiding disability (ghisysy) ${ }^{18}$, and attempts to influence other parties that contain lies (taghrir) ${ }^{19}$.

Securities meet the Sharia Principles in the Capital Market so that they become sharia effects if the following aspects do not conflict with Sharia Principles in the Capital Market ${ }^{20}$ which include: (1) Activities and types of business, as well as ways of managing the business of the party that issues the securities; (2) Agreement, method of management, and assets of an Investment Fund; (3) Contracts, management methods, and financial assets that make up the Asset Backed Securities portfolio issued by the Asset Backed Securities Collective Investment Contract; (4)

Agreement, method of management and assets of Real Estate Investment Trust in

\footnotetext{
${ }^{13} \mathrm{An}$ example of trading on goods that are not yet owned is Sharia Securities trading that is not yet owned (bai 'al-ma'dum / short selling).

${ }^{14}$ What is meant by "insider information" is Material Information held by insiders that is not yet available to the public as referred to in the explanation of Article 95 of the Law on Capital Markets.

${ }^{15}$ Actions included in the hoarding category (ihtikar) include: (1) Pooling interest, namely transaction activity on a liquid that seems liquid, whether accompanied by price movements or not, at a certain period and only enlivened by a group of members Certain Stock Exchanges (in buying or selling); (2) Cornering, namely the pattern of transactions intended to create a pseudo supply that causes prices to fall in the morning and causes public investors to sell shares but do not yet have shares sold (short selling).

${ }^{16}$ What is meant by "bribes (risywah)" is a gift that aims to take something that is not his right, justify the false and make the false as something that is true.

${ }^{17}$ Acts classified as fraud (tadlis) include: (1) conducting transactions in advance on the basis of information that someone will carry out transactions in large volumes (front running); and (2) misleading information, namely making statements or providing information that is materially incorrect or misleading so that it affects the price of Securities.

${ }^{18}$ Actions included in the effort to explain the superiority or privilege and conceal the defect (ghisysy) include: (1) Establishing a closing price (marking at the close), i.e. placing a buy or sell order at the end of the trading day aimed at creating a closing price as desired; and (2) Transactions from a group of actors with roles as buyers and sellers in turn and carried out with a reasonable volume that gives the impression that an active Securities is traded (alternate trade).

${ }^{19}$ Actions that fall under the category of attempts to influence other parties that contain lies (taghrir) include: (1) Pseudo-trade that does not change ownership in order to form prices by giving the impression that prices are formed through transactions that have a reasonable impression and to be actively traded (wash sale); and (2) Transactions that occur through the installation of buy and sell orders at almost the same time span that occur due to the agreement of the buyer and seller beforehand in the context of forming prices or other interests both inside and outside the stock exchange (prearrange trade).
}

${ }^{20}$ Financial Services Authority Regulations No.15/POJK.04/2015 Article 3 
Evan Hamzah Muchtar :The Shariah Compliance Analysis...

the form of Collective Investment Contract; (5) The contract and portfolio in the form of a collection of receivables or housing finance; (6) The contract, method of management, and / or assets underlying the Sukuk; or (7) A contract, method of management, and / or assets that underlie other Securities determined by the Financial Services Authority.

Based on the Financial Services Authority Regulation No.35 / POJK.04 / 2017 concerning Criteria and Issuance of Sharia Securities, the criteria for shares included in the sharia category are as follows: ${ }^{21}$

1. Do not conduct activities and types of business that are contrary to Islamic principles in the Capital Market which include:

a. Gambling and games classified as gambling;

b. Ribawi financial services;

c. Buying and selling risks that contain elements of uncertainty (ghahar) and / or gambling (maisir).

d. Producing, distributing, trading and / or providing illicit goods or services because of their substance (haram li-dzatihi), haram not because of its substance (haram li-ghairihi) stipulated by the National Sharia Council Indonesian Ulema Council, damaging morals or being mudharat; and / or other goods or services that are contrary to Islamic principles in the capital marketTidakmelakukantransaksi yang bertentangandenganprinsipsyariah di Pasar Modal

2. Meet the financial ratios as follows:

a. Total interest-based debt compared to total assets is not more than $45 \%$ (forty-five percent); and

b. Total interest income and other non-halal income compared to total business income and other income is not more than $10 \%$ (ten percent).

${ }^{21}$ Financial Services Authority Regulations No.35/POJK.04/2017 Article 2 Section (1)

Sharia Securities are securities as referred to in Law Number 8 of 1995 concerning Capital Markets and their implementing regulations that are not in conflict with the Sharia Principles in the Capital Market, including: (1) contracts, management methods, business activities; (2) assets that form the basis of a contract, how to manage business activities; and / or (3) assets related to the intended securities and their issuers. 
Evan Hamzah Muchtar :The Shariah Compliance Analysis...

\section{ACADEMIC AND PRACTICE OPINION REGARDING THE SHARIA STOCK SCREENING PROCESS}

In general, the screening process has two aspects that must be fulfilled by issuers so that the company can enter the Islamic stock index, namely the qualitative and quantitative aspects. Qualitative aspects include the criteria of business objects, whether the company is engaged in a sector that is prohibited by the elements of usury, gharar, and maysir. While the quantitative aspect (financial ratio) is to see the comparison between total interest-based debt compared to total assets and to compare total interest income and other non-halal income with total income. ${ }^{22}$

The problem that arises and gives rise to debate among academics and Islamic practitioners is the issue of screening the issuers listed on the Islamic stock index. Taqiyuddin al-Nabhani in his book, an-Nizam al-Iqtishadifil Islam (Economic System in Islam) ${ }^{23}$, revealed that stock transactions are considered legally null, because there are only one-sided transactions from investors who include their capital by buying shares in the capital market without any negotiations or negotiations with the company. This was confirmed by Yusuf al-Sabatin who said that in the matter of stock transactions it was not appropriate to use the MaslahahMursalah analysis. Moreover, according to him that MaslahahMursalah is a weak source of law, because its blasphemy is not based on the qat'i proposition. ${ }^{24}$

The statement of the two ulama above contradicts the thought of GholamrezaZandi ${ }^{25}$, according to him that in every capital market country is very important as one of the driving forces of a country's economy. Therefore, the equity market system must be monitored properly. The screening methodology is one of the important elements in supervising issuers in the capital market that needs to be improved from time to time. This is due, the status of shares in a country will affect the decision of investors, especially Muslim investors to invest.

\footnotetext{
${ }^{22}$ Financial Services Authority Regulations 35/POJK.04/2017 Article 2 Section (1)

${ }^{23}$ Al-Nabhani, Taqiyuddin.an-Nizam al-Iqtishadifil Islam, (Beirut: Dar el Ummah, 2004), p.3

${ }^{24} \mathrm{Al}$-Sabatin, Yusuf, al-Buyu' al-Qadimahwa al-Mu'asirahwa al-Burshat al-Mahaliyyahwa alDuwaliyyah, (Beirut: Dar el Bayariq, 2002), p.53

${ }^{25}$ GholamrezaZandi, dkk, "Stock Market Screening: An Analogical Study on Conventional and Shariah-Compliant Stock Markets," Asian Social Science; Vol. 10, No. 22 , 2014, p. 270.
} 
Evan Hamzah Muchtar :The Shariah Compliance Analysis...

ZamirIqbal ${ }^{26}$ argues that although there are elements of gharar stock transactions on the capital market, but it is acceptable because all transactions are based on fundamental analysis of economic variables and are subject to an acceptable level of uncertainty, in the sense that it is not entirely pure speculation. He even emphasized that basically the concept of the stock market was in accordance with the principles of sharia, it's just that not all businesses listed on the stock market were fully in accordance with sharia. Therefore, it is important to do a screening of issuers who violate the rules of Islamic law. This problem is certainly a challenge for the development of the Islamic capital market.

The same statement was delivered by Sami al-Suwailem ${ }^{27}$, who stated that the Islamic capital market was in accordance with sharia principles. He further illustrated, that transactions in the Islamic capital market are different from gambling games that contain speculative elements. In a lottery game, for example, the possibility of winning to both parties who play is impossible, because it is a zero sum game, where the winner is one party and the other is disadvantaged. Whereas in the stock market, all participants have an equal chance of winning.

M.A. Mannan said that the Islamic securities market is possible to be built by evaluating conventional securities market practices that are contrary to Islamic principles. The essence of Islamic economics is an economy with profit sharing. Therefore the Islamic securities market framework can be built on the basis of a number of mumalah contract concepts such as musharaka, mudaraba, murabahah and salam. ${ }^{28}$

M. Ali El-Ghari stated that the stock exchange is one of the most vital financial intermediary institutions in the modern economy. Its functions complement other institutions such as commercial banks, insurance companies and other institutions. ${ }^{29} \mathrm{M}$. Ali El-Ghari further mentioned four functions of the stock exchange, namely: (1) Instruments that are able to attract savings and direct them

\footnotetext{
26ZamirIqbal, An Inroduction to Islamic Finance:Theory and Practice, Singapura: Jhon Wiley \& Sons, 2007, p.68 \& 173 .

${ }^{27}$ Sami Al-Suwailem, "Towards Objective Measure of Gharar in Exchange," Islamic Economic Studies, Vol.7.No.1 dan 2, 2000, p.80.

${ }^{28}$ Mannan, M. Abdul, Understanding Islamic Finance: A Study of the Securities Market in An Islamic Framework, (Jeddah: IDB IRTI, 1993) , p.25

${ }^{29}$ El-Ghari, M.Ali, “Towards an Islamic Stock Market”, Islamic Economic Studies Journal, Vol.1 No.1, 1993, p.3
} 
Evan Hamzah Muchtar :The Shariah Compliance Analysis...

for investment purposes; (2) Savers and investors' preferences can be adjusted according to liquidity and risk; (3) Investment risk can be assessed, and (4) Effective tools are available to evaluate the performance of the issuer and there are information facilities for investment. ${ }^{30}$

Seif Tag el-Din explained the main issue of the difference between the development of conventional and Islamic capital markets, which is related to the elimination of usury (interest) and gharar. ${ }^{31}$ The elimination of usury from the Islamic economy will also help minimize speculative sales thereby protecting investors. ${ }^{32}$

Based on the provisions, ${ }^{33}$ the ratio between total interest-based debt compared to total assets is not more than $45 \%$ (forty-five percent) and the comparison of total interest income and other non-halal income with total income of no more than $10 \%$ (ten percent). This indicates that issuers registered in the Islamic stock index are allowed to use interest-based debt and obtain income.

In this regard, SofyanSafriHarahap ${ }^{34}$ said that in the future, it was hoped that this compromise could gradually be abolished, not to continue to be debated among intellectuals. As a step used in the framework of a compromise that is to do the process of purification of income (cleansing or purifying process) so that there is no doubt about the income that may be mixed with non-halal. Because in Islam it is required that the halal must be separated from the haram in order to meet the investment criteria that are based on sharia principles.

${ }^{30}$ El-Ghari, M.Ali, “Towards an ... p.4

31 El-Din, Seif I Tag, "Capital and Money Market of Muslims: The Emerging Experience in Theory and Practice", Kyoto Bulletin of Islamic Area Studies, 1-2, 2007, p.69

${ }^{32} \mathrm{M}$ UmerChapra commented on the writings of Mokhtar M. Metwally. In general, M. UmerChapra opposes the regulation of stability through the determination of share prices by the Management Committee and the existence of certain periods for stock trading. See Chapra, M Umer, "Comments about The Role of Stock Exchange in An Islamic Economy by Mokhtar M. Metwally on J. Res Islamic Econ, Vol.2 No.1, 1984", J. Res Islamic Econ, Vol.3 No .1, 1985, p.80

Previously, Mokhtar M. Metwally through the writing "The Role of Stock Exchange in An Islamic Economy" stated to maintain price stability through two steps, namely: (1) Management Committee in the stock exchange must determine the maximum stock price for each issuer with an interval of no more than three month, and (2) Shares are traded only in certain trading periods. See Metwally, Mokhtar M, "The Role of Stock Exchange in An Islamic Economy", J. Res Islamic Econ, Vol.2 No.1, 1984, p.22

Similar to M UmerChapra, Ahmad Abdel Fattah El-Sakhar also stated that price fixation must be avoided. See El-Ashkar, Ahmad Abdel Fattah, "Towards an Islamic Stock Exchange in a Transitional Stage", Islamic Economic Studies, Vol. 3 No.1, 1995, p.1

33 Regulation of the Financial Services Authority No. 35/POJK.04/2017 Article 2 Section (1)

${ }^{34}$ SofyanSafriHarahap, TeoriAkuntansi. EdisiRevisi. Jakarta: PT. Raja GrafindoPersada, 2007,p.293- 
Evan Hamzah Muchtar :The Shariah Compliance Analysis...

\section{Shariah Compliance Analysis Based On Finantial Ratio Aspects}

Based on the Decision of the Board of Commissioners of the Financial Services Authority Number Kep-24 / D.04 / 2018 regarding the List of Sharia Securities, 368 Islamic shares were recorded. Of the 368 Islamic shares there are 119 listed companies that are always registered with ISSI. Of the 119 issuers who revealed the adoption of open corporate governance guidelines in the Annual Report as many as 59 issuers. Then 59 issuers are sorted according to the profits earned by the issuers, then the top 50 companies are selected as research samples.

Issuers selected as research samples are always listed on the Indonesian Sharia Stock Index (ISSI) since it was first launched in 2011 until the first period of 2018. This indicates that the 50 issuers always meet Islamic principles in accordance with applicable regulations, both from business aspects as well as financial aspects.

Fulfillment of sharia principles from the business aspect through screening of activities, types of business and transactions carried out by issuers does not conflict with Sharia Principles in the Capital Market. Whereas the fulfillment of sharia principles from the financial aspect through screening calculation of the ratio of interest-based debt compared to total assets is not more than $45 \%$ and the ratio of interest income compared to total income is not more than $10 \%$.

The following is the level of sharia compliance from the financial aspects of the research sample based on the issuer's financial statements ending December 31, 2017:

Tabel 2

Sharia Compliance Based On Finantial Ratio Aspects

\begin{tabular}{|c|c|c|c|}
\hline No. & Code & $\begin{array}{c}\text { Interest Based Debt/ } \\
\text { Total Asset }\end{array}$ & $\begin{array}{c}\text { Interest Income/ } \\
\text { Total Revenue }\end{array}$ \\
\hline 1 & AALI & $15.92 \%$ & $0.14 \%$ \\
\hline 2 & AKRA & $18.54 \%$ & $0.24 \%$ \\
\hline 3 & ALKA & $14.77 \%$ & $0.00 \%$ \\
\hline 4 & AMFG & $23.82 \%$ & $0.05 \%$ \\
\hline 5 & ANTM & $29.87 \%$ & $2.05 \%$ \\
\hline 6 & APLN & $32.07 \%$ & $1.22 \%$ \\
\hline 7 & ASGR & $35.70 \%$ & $0.29 \%$ \\
\hline 8 & ASII & $25.34 \%$ & $0.96 \%$ \\
\hline 9 & ASRI & $37.76 \%$ & $1.09 \%$ \\
\hline 10 & AUTO & $4.92 \%$ & $0.51 \%$ \\
\hline 11 & BKSL & $15.65 \%$ & $2.07 \%$ \\
\hline 12 & BRAM & $11.02 \%$ & $0.03 \%$ \\
\hline
\end{tabular}


Evan Hamzah Muchtar :The Shariah Compliance Analysis...

\begin{tabular}{|c|c|c|c|}
\hline No. & Code & $\begin{array}{c}\text { Interest Based Debt/ } \\
\text { Total Asset }\end{array}$ & $\begin{array}{c}\text { Interest Income/ } \\
\text { Total Revenue }\end{array}$ \\
\hline 13 & BRPT & $25.05 \%$ & $0.15 \%$ \\
\hline 14 & BSDE & $19.65 \%$ & $2.57 \%$ \\
\hline 15 & DSSA & $31.29 \%$ & $0.62 \%$ \\
\hline 16 & DVLA & $8.40 \%$ & $0.49 \%$ \\
\hline 17 & EPMT & $1.52 \%$ & $0.26 \%$ \\
\hline 18 & FAST & $7.51 \%$ & $0.66 \%$ \\
\hline 19 & GMTD & $5.63 \%$ & $1.45 \%$ \\
\hline 20 & HRUM & $5.22 \%$ & $1.14 \%$ \\
\hline 21 & ICBP & $4.11 \%$ & $1.13 \%$ \\
\hline 22 & INDR & $32.27 \%$ & $0.03 \%$ \\
\hline 23 & INTP & $0.37 \%$ & $3.60 \%$ \\
\hline 24 & ITMG & $0.57 \%$ & $0.20 \%$ \\
\hline 25 & JRPT & $1.37 \%$ & $0.84 \%$ \\
\hline 26 & JTPE & $22.78 \%$ & $0.11 \%$ \\
\hline 27 & KAEF & $33.13 \%$ & $0.22 \%$ \\
\hline 28 & KDSI & $37.90 \%$ & $0.01 \%$ \\
\hline 29 & KIJA & $35.87 \%$ & $4.17 \%$ \\
\hline 30 & KKGI & $1.27 \%$ & $0.69 \%$ \\
\hline 31 & KLBF & $1.92 \%$ & $0.67 \%$ \\
\hline 32 & LPKR & $24.37 \%$ & $0.75 \%$ \\
\hline 33 & LSIP & $0.11 \%$ & $1.21 \%$ \\
\hline 34 & MYOR & $29.86 \%$ & $0.18 \%$ \\
\hline 35 & PJAA & $21.22 \%$ & $2.52 \%$ \\
\hline 36 & SCBD & $4.92 \%$ & $1.32 \%$ \\
\hline 37 & SMSM & $4.47 \%$ & $0.10 \%$ \\
\hline 38 & SONA & $29.58 \%$ & $0.45 \%$ \\
\hline 39 & SRSN & $28.32 \%$ & $0.00 \%$ \\
\hline 40 & SSIA & $25.65 \%$ & $1.70 \%$ \\
\hline 41 & TCID & $1.94 \%$ & $0.62 \%$ \\
\hline 42 & TLKM & $17.87 \%$ & $1.12 \%$ \\
\hline 43 & TOTL & $3.19 \%$ & $1.13 \%$ \\
\hline 44 & TPIA & $21.17 \%$ & $0.37 \%$ \\
\hline 45 & TRST & $19.28 \%$ & $0.00 \%$ \\
\hline 46 & UNIC & $10.28 \%$ & $0.29 \%$ \\
\hline 47 & UNTR & $5.69 \%$ & $1.57 \%$ \\
\hline 48 & UNVR & $18.25 \%$ & $0.01 \%$ \\
\hline 49 & VOKS & $22.94 \%$ & $0.04 \%$ \\
\hline 50 & WIKA & $19.73 \%$ & $0.92 \%$ \\
\hline
\end{tabular}

Source: processed by researchers 
Evan Hamzah Muchtar :The Shariah Compliance Analysis...

\section{E. CONCLUSION}

Sharia principles in the Capital Market are Islamic legal principles in Sharia Activities in the Capital Market based on the fatwa of the National Sharia Council Indonesian Ulema Council (DSN MUI), as long as the fatwa referred does not conflict with this Financial Services Authority Regulation and / or other Financial Services Authority Regulations based on on the MUI DSN fatwa.

Securities meet the Sharia Principles in the Capital Market so that it becomes a sharia effect if the following aspects do not conflict with the Sharia Principles in the Capital Market and meet the provisions of the financial ratio of total debt based on interest compared to total assets of no more than $45 \%$ and the total interest income and other non-halal income compared to total operating revenues and other income not more than $10 \%$.

Differences of opinion among academics and Islamic practitioners regarding the issue of screening of listed companies on the Islamic stock index are expected to not occur again by purifying the issuer's revenue. Based on research, all issuers are in compliance with sharia compliance based on finantial aspect ratios.

\section{REFERENCES}

Al-Nabhani, Taqiyuddin.an-Nizam al-Iqtishadifil Islam, Beirut: Dar el Ummah, 2004

Al-Sabatin, Yusuf, al-Buyu' al-Qadimahwa al-Mu'asirahwa al-Burshat al-Mahaliyyahwa al-Duwaliyyah, Beirut: Dar el Bayariq, 2002

Al-Suwailem, Sami, "Towards Objective Measure of Gharar in Exchange," Islamic Economic Studies, Vol.7.No.1 dan 2, 2000

Chapra, M Umer, "Comments about The Role of Stock Exchange in An Islamic Economy by Mokhtar M. Metwally on J. Res Islamic Econ, Vol.2 No.1, 1984", J. Res Islamic Econ, Vol.3 No.1, 1985

El-Ashkar, Ahmad Abdel Fattah, "Towards an Islamic Stock Exchange in a Transitional Stage", Islamic Economic Studies, Vol. 3 No.1, 1995

El-Din, Seif I Tag, "Capital and Money Market of Muslims: The Emerging Experience in Theory and Practice", Kyoto Bulletin of Islamic Area Studies, 1-2, 2007

El-Ghari, M.Ali, "Towards an Islamic Stock Market”, Islamic Economic Studies Journal, Vol.1 No.1, 1993

Financial Service Authority, Roadmap Pasar Modal Syariah 2014-2019, Jakarta: OtoritasJasaKeuangan, 2014

Financial Service Authority, PeraturanOtoritasJasaKeuangan No.15/POJK.04/2015 tentangPenerapanPrinsipSyariah Di Pasar Modal, Jakarta: OtoritasJasaKeuagan, 2015 
Evan Hamzah Muchtar :The Shariah Compliance Analysis...

Financial Service Authority, PeraturanOtoritasJasaKeuangan No.35/P0JK.04/2014 tentangSekretaris Perusahaan Emitenatau Perusahaan Publik, Jakarta: OtoritasJasaKeuagan, 2015

GholamrezaZandi, dkk, "Stock Market Screening: An Analogical Study on Conventional and Shariah-Compliant Stock Markets," Asian Social Science; Vol. 10, No. 22 , 2014

Harahap, SofyanSafri, TeoriAkuntansi. EdisiRevisi. Jakarta: PT. Raja GrafindoPersada, 2007

Indonesia Stock Exchange, LaporanTahunan 2018, Jakarta: PT Bursa Efek Indonesia, 2019

Iqbal, Zamir, AnInroduction to Islamic Finance:Theory and Practice, Singapura: Jhon Wiley \& Sons, 2007

Mannan, M. Abdul, Understanding Islamic Finance: A Study of the Securities Market in An Islamic Framework, Jeddah: IDB IRTI, 1993

Metwally, Mokhtar M, "The Role of Stock Exchange in An Islamic Economy", J. Res Islamic Econ, Vol.2 No.1, 1984

Soemitra, Andri, MasaDepanPasar Modal Syariah Di Indonesia EdisiRevisi, Jakarta: Kencana, 2016. 